University of Nebraska - Lincoln

DigitalCommons@University of Nebraska - Lincoln

USDA National Wildlife Research Center - Staff Publications
U.S. Department of Agriculture: Animal and Plant Health Inspection Service

2013

\title{
Laboratory efficacy of an anthraquinone-based repellent for reducing bird damage to ripening corn
}

James C. Carlson

USDA/APHIS/WS National Wildlife Research Center, james.c.carlson@aphis.usda.gov

Shelagh K. Tupper

USDA-APHIS, Wildlife Services' National Wildlife Research Center

Scott J. Werner

USDA-APHIS-Wildlife Services, scott.j.werner@aphis.usda.gov

Susan E. Pettit

USDA-APHIS, Wildlife Services' National Wildlife Research Center

Michele M. Santer

Arkion Life Sciences

See next page for additional authors

Follow this and additional works at: https://digitalcommons.unl.edu/icwdm_usdanwrc

Carlson, James C.; Tupper, Shelagh K.; Werner, Scott J.; Pettit, Susan E.; Santer, Michele M.; and Linz, George M., "Laboratory efficacy of an anthraquinone-based repellent for reducing bird damage to ripening corn" (2013). USDA National Wildlife Research Center - Staff Publications. 1225.

https://digitalcommons.unl.edu/icwdm_usdanwrc/1225

This Article is brought to you for free and open access by the U.S. Department of Agriculture: Animal and Plant Health Inspection Service at DigitalCommons@University of Nebraska - Lincoln. It has been accepted for inclusion in USDA National Wildlife Research Center - Staff Publications by an authorized administrator of DigitalCommons@University of Nebraska - Lincoln. 
Authors

James C. Carlson, Shelagh K. Tupper, Scott J. Werner, Susan E. Pettit, Michele M. Santer, and George M. Linz 


\title{
Laboratory efficacy of an anthraquinone-based repellent for reducing bird damage to ripening corn
}

\author{
James C. Carlson a, ${ }^{\mathrm{a},}$, Shelagh K. Tupper ${ }^{\mathrm{a}}$, Scott J. Werner ${ }^{\mathrm{a}}$, Susan E. Pettit ${ }^{\mathrm{a}}$, \\ Michele M. Santer ${ }^{b}$, George M. Linz ${ }^{\mathrm{c}}$ \\ a United States Department of Agriculture, Animal and Plant Health Inspection Service, Wildife Services, National Wildlife Research Center, 4101 LaPorte \\ Avenue, Fort Collins, CO 80521-2154, USA \\ b Arkion Life Sciences, 551 Mews Drive-Suite J, New Castle, DE 19720, USA \\ c United States Department of Agriculture, Animal and Plant Health Inspection Service, Wildife Services, National Wildlife Research Center, North Dakota \\ Field Station, 2110 Miriam Circle, Bismarck, ND 58501-2502, USA
}

\section{A R T I C L E I N F O}

Article history:

Accepted 23 January 2013

Available online 5 March 2013

\section{Keywords:}

Agelaius phoeniceus

Aversion

Chemical repellent

\begin{abstract}
A B S T R A C T
Wildlife repellents provide a non-lethal alternative for managing agricultural impacts associated with wildlife depredation. To evaluate a potential bird repellent for ripening corn, we conducted a feeding experiment at the United States Department of Agriculture, National Wildlife Research Center with 66 red-winged blackbirds (Agelaius phoeniceus). Using a two-choice experimental design we tested the efficacy of Avipel repellent (a.i. 50\% 9,10-anthraquinone) on ripening sweet corn. Red-winged blackbirds consumed an average of $8.6 \% \pm 0.9 \%$ of kernels from untreated ears and $5.3 \% \pm 1.1 \%$ from ears treated with anthraquinone. The interaction between anthraquinone concentration and corn treatment suggests a positive concentration-response for red-winged blackbirds. Odds ratio analysis suggests red-winged blackbirds were 1.4 times more likely to damage untreated sweet corn compared to treated sweet corn. These results suggest efficacy of anthraquinone-based products as red-wing blackbird repellents for ripening corn. Moreover, exposure to anthraquinone-based repellents may reduce consumption of a food matrix that receives little to no direct anthraquinone exposure. Supplemental research is recommended to evaluate anthraquinone-based repellents under field conditions, including the establishment of a chemical tolerance for food and feed use.
\end{abstract}

Published by Elsevier B.V.

\section{Introduction}

Birds are known to cause significant damage in agriculture through the depredation of corn destined for human and livestock consumption (Stone et al., 1972). Blackbirds, specifically red-winged blackbirds (Agelaius phoeniceus), and common grackles (Quiscalus quiscula) are the species most commonly associated with depredation of

\footnotetext{
* Corresponding author. Tel.: +1 970266 6127; fax: +1970266 6135 . E-mail addresses: james.c.carlson@aphis.usda.gov, jimskipow@gmail.com (J.C. Carlson).
}

ripening sweet and field corn (DeGrazio, 1964; Dolbeer, 1990; Woronecki et al., 1981). Within the United States damage to ripening sweet corn begins 15 days after silking (DAS) when corn kernels are in the milk stage (R3 growth stage). Sweet corn is typically harvested 16-20 DAS leaving a short window for damage by birds. Damage to field corn also begins during R3 but continues through the dough stage (R4) up to 30 DAS due to the delay in harvest of field corn (Dolbeer, 1990). Blackbirds are known to damage corn by slitting the husk and pecking out the contents of the exposed kernels (Dolbeer, 1980).

Estimates of the amount of bird damage to ripening corn were evaluated recently for North Dakota where $0.7 \%$ of the 
809,372 hectare corn crop was damaged by birds in 2008 (Klosterman et al. 2011). This is consistent with historical estimates of bird damage to ripening corn, which suggest that less than $1 \%$ is destroyed annually in the United States of America (Conover, 1984; Dolbeer, 1990; Wywialowski, 1993). Bird damage tends to be spatially clustered with damage concentrated in a small percentage of fields that can have $>10 \%$ damage (Conover, 1984; Wywialowski, 1993). This spatial heterogeneity in bird damage may be a function of local habitat characteristics such as proximity to water sources, roosting habitat or alternative food sources (Dolbeer, 1980, 1990; Wywialowski, 1993). Additionally, bird damage may be more significant for sweet corn producers because even slight damage can prevent corn from being sold for human consumption (Dolbeer, 1990). Thus, even minimal bird damage $(<1 \%)$ to ears of sweet corn can potentially cause severe economic losses for producers.

Nonlethal chemical repellents are a socially acceptable approach to managing avian depredation of agricultural crops (Cummings et al., 2002a, 2002b; Linz et al., 2006; Werner et al., 2011). Previous studies assessing chemical repellents, for ripening field and sweet corn, have shown mixed results in reducing damage by birds (Woronecki et al., 1981). Anthraquinone was identified as a bird repellent in the 1940s (Heckmanns and Meisenheimer, 1944). Anthraquinone is a cathartic purgative that acts principally on the large intestine and consumption of anthraquinone, by birds, likely causes malabsorption and dehydration (Werner et al., 2009, 2011). Since its initial discovery numerous laboratory and field efficacy studies have demonstrated the repellent qualities of anthraquinone to reduce damage by bird species such as red-winged blackbirds, common grackles, Canada geese (Branta canadensis), ring-necked pheasants (Phasianus colchicus) and sandhill cranes (Grus canadensis; Blackwell et al., 2001; Werner et al., 2009, 2011).

Anthraquinone-based bird repellents have been shown to reduce sand hill crane consumption of whole kernel corn seed (Blackwell et al., 2001). The demonstrated efficacy of anthraquinone led to an Federal Insecticide, Fungicide, and Rodenticide Act, Emergency Use Exemption (FIFRA Section 18) to protect newly planted field and sweet corn from damage caused by sandhill cranes and red-winged blackbirds within nine states (Eisemann et al., 2011). Anthraquinone has also been shown to effectively protect ripening sunflower from common grackles and red-winged blackbirds in field enclosure testing (Werner et al., 2010, 2011). No tests of the efficacy of anthraquinone for ripening field or sweet corn have been conducted.

The purpose of our study was to assess the efficacy of anthraquinone as a bird repellent for ripening corn. Our objectives were two-fold: First, demonstrate if anthraquinone can modify behavior to reduce bird depredation of ripening sweet corn; second, quantify the concentration-response of anthraquinone for red-winged blackbirds damaging ripening sweet corn. To achieve these goals, we conducted controlled feeding experiments using whole ears of milk stage sweet corn exposed to red-winged blackbirds.

\section{Materials and methods}

\subsection{Facilities, maintenance and diets}

Red-winged blackbird feeding experiments were conducted at the United States Department of Agriculture (USDA), National Wildlife Research Center (NWRC) in Fort Collins, CO, USA. Testing was conducted August-September, 2010. We used 66 red-winged blackbirds for repellency experiments. We tested anthraquinone on sweet corn and not field corn cultivars. Our justification was two-fold. First, sweet corn and field corn are structurally very similar. Sweet corn is a cultivar of field corn that is incapable of completing the formation of corn starch (Erwin, 1951). Sweet corn differs from field corn by having elevated sucrose levels caused by mutations of specific genes (i.e. su1, se1, sh2) known to alter starch synthesis (Schultz and Juvik, 2004). Second, red-winged blackbirds will preferentially select sugar solutions high in sucrose (Martinez del Rio, 1990). This suggests red-winged blackbirds can metabolize sucrose and consequently they will select sweet corn cultivars over field corn cultivars with low sucrose concentrations. Thus, we believe a repellent that is effective at deterring red-winged blackbirds from damaging sweet corn will also be effective against red-winged blackbirds in field corn.

The capture, care, and use of all birds within our feeding experiments were approved by the NWRC Animal Care and Use Committee (NWRC Study QA-1748; J.C. Carlson - study director). We maintained all blackbirds in $4.9 \mathrm{~m} \times 2.4 \mathrm{~m} \times 2.4 \mathrm{~m}$ cages ( $40-50$ birds/cage) within a wire mesh-sided building for $\geq 2$ weeks prior to our experiments (i.e., quarantine, holding). Blackbird experiments were conducted in individual cages $(0.9 \mathrm{~m} \times 1.8 \mathrm{~m} \times 0.9 \mathrm{~m})$ within a wire mesh-sided building. We provided all birds free access to grit and maintenance diet during quarantine and holding. The maintenance diet included two parts millet, one part cracked corn, one part milo, and one part safflower. We provided water ad libitum to all birds throughout our experiment.

\subsection{Pretest and acclimation}

Ripening sweet corn was hand harvested from fields when ears were at full milk stage. Husks were not removed from ears prior to repellent testing. All corn used in our experiments was destined for human consumption and purchased from Sakata Farms Inc. (Brighton, CO, USA). All sweet corn was used within 2 weeks of harvest and corn was stored in walk in coolers until they were treated with anthraquinone and exposed to birds.

We offered all red-winged blackbirds $75 \mathrm{~g}$ of cracked corn daily, for 5 days of acclimation, in individual cages. We ranked blackbirds based upon average pretreatment consumption of cracked corn and assigned them to one of six treatment groups ( $n=11$ birds/group); such that each group was similarly populated with birds that exhibited high-low daily consumption. We then randomly assigned one of the six different anthraquinone concentrations to each group. 
We used Avipel ${ }^{\circledR}$ (50\% 9,10-anthraquinone; Arkion Life Sciences, New Castle, DE, USA) to repel blackbirds from ripening sweet corn. Avipel ${ }^{\circledR}$ was mixed with tap water to produce six different, $11.356 \mathrm{~L}$ concentrations of anthraquinone by volume $(0.1 \%, 0.25 \%, 0.5 \%, 0.75 \%, 1 \%$, and $2 \%)$. All repellent concentrations were stored in $18.925 \mathrm{~L}$ buckets at room temperature. Anthraquinone concentrations were mixed by hand for $5 \mathrm{~min}$. each day before treating. Each ear was treated with anthraquinone by immersing it in its designated bucket of anthraquinone for $2 \mathrm{~s}$. Ears were then hung overnight in nylon mesh bags to dry.

\subsection{Experimental design}

We used a two-choice testing paradigm to assess behavioral modification and quantify concentration-response for red-winged blackbirds. All birds received one treated and one untreated ear of sweet corn, daily, for 4 days. Ears of corn, with husks present, were placed vertically on wooden stands within cages. Birds were allowed to choose between a treated and untreated ear of sweet corn for $24 \mathrm{~h}$ before a fresh set of treated and untreated ears were offered to birds. Ears of sweet corn contained substantially more corn that the red-winged blackbird consumed in a $24 \mathrm{~h}$ period, allowing our experimental birds free choice to discriminate between treated or untreated ears of corn. The north-south placement of treated and untreated corn was randomized on the first day and alternated on subsequent days throughout the experiment. We used two criteria to measure corn damage. First, we estimated percent damage using methods reported by Klosterman et al. (2011). Length and the circumference of each ear of corn were measured: circumference was measured at the center point of the ear. We then measured the length and width of the area from which kernels were removed from the ear of corn. Percent damage was calculated as: percent $(\%)=$ damage $\left(\right.$ length ${ }^{*}$ width $) /$ Ear (length*circumference). Second, we used a binary measurement (presence/absence) to assess damage to sweet corn. If ears showed signs of husk slitting or kernel consumption the ear was recorded as "damaged". If no damage to the husk and kernels were observed the ear was recorded as "not damaged". We conducted two separate analyses because sweet corn growers will need a repellent that prevents birds from damaging ears while field corn producers will need a repellent that reduces corn consumption. Thus, it was important for us to demonstrate that anthraquinone can reduce both the percent of corn consumed and the number of ears affected.

\subsubsection{Statistical analysis}

Red-winged blackbird percent damage data showed evidence of heteroscedasticity so we used Welch's Analysis of Variance (ANOVA) to analyze data. All percent damage was averaged over the four days of data collection to produce a single treated and a single control estimate for each bird. Fixed effects included anthraquinone concentration $(0.1 \%, 0.25 \%, 0.5 \%, 0.75 \%, 1 \%$, and $2 \%)$, treatment group (treated vs. untreated ears) and the interaction between anthraquinone concentration and treatment group. Binary analysis of red-winged blackbird damage was conducted using generalized linear mixed effects logistic regression. The response variable was binary (damage/no damage). Fixed effects included anthraquinone concentration $(0.1 \%, 0.25 \%, 0.5 \%, 0.75 \%, 1 \%$, and $2 \%)$, treatment group (treated vs. untreated ears) and the interaction between anthraquinone concentration and treatment groups. Bird subjects were included as random effects and repeated measurements of corn damage by birds were made over the four days of data collection. For binary data analysis we used odds ratios to measure effect size of corn damage between anthraquinone treated and untreated ears of sweet corn.

\subsection{Anthraquinone residue analyses}

We used reversed-phase, high performance liquid chromatography (HPLC; Table 1) with ultraviolet detection to quantify anthraquinone residues (i.e., actual concentrations) for our corn husk and kernel samples $( \pm 1 \mathrm{ppm}$ anthraquinone). Residue analyses for corn husk and kernel samples were conducted independently. We collected $20 \mathrm{~g}$ samples of husk and kernels from three ears of sweet corn from each treatment group used in our experiment (18 ears total). All samples were labeled and shipped to Arkion Life Sciences for residue analyses. Samples were received by Arkion Life Sciences within $24 \mathrm{~h}$ of shipment, logged in, and immediately transferred to a $4{ }^{\circ} \mathrm{C}$ refrigerator where they were stored for the duration of the analysis period.

We extracted and analyzed triplicate subsamples of corn husk and kernels from each ear of sweet corn. Samples of each type were fortified with $350 \mathrm{ppm}$ and $1000 \mathrm{ppm}$ anthraquinone, and extracted to determine the recovery rate for the assay. We weighed $1.0( \pm 0.2) \mathrm{g}$ of corn husk

Table 1

Anthraquinone residues detected on corn husks and kernels exposed to red-wing blackbird (RWBL) in a two choice experiments. Residue analysis was conducted by Arkion Life Sciences, December 2010.

\begin{tabular}{lccccc}
\hline Anthraquinone concentration & Husk PPM $(\bar{\chi})^{\mathrm{a}}$ & Husk PPM $(\text { SEM })^{\mathrm{b}}$ & Kernel PPM $(\bar{\chi})$ & Kernel PPM $($ SEM $)$ & Count $(\bar{N})^{\mathrm{c}}$ \\
\hline $0.10 \%$ & 340.5 & 18.89 & 0.22 & 0.03 & 9 \\
$0.25 \%$ & 1019.53 & 21.12 & 1.26 & 0.24 & 1.27 \\
$0.50 \%$ & 2347.34 & 320.25 & 5.2 & 5.41 & 9 \\
$0.75 \%$ & 2600.09 & 205.48 & 12.1 & 8.88 & 9 \\
$1.00 \%$ & 4911.5 & 125.95 & 27.75 & 13.44 & 9 \\
$2.00 \%$ & 9618.93 & 512.38 & 34.25 & 9 \\
\hline
\end{tabular}

a Mean concentration of anthraquinone, in parts per million (PPM), found on corn husks and kernels.

b Standard error associated for mean anthraquinone concentrations from residue analysis of corn husks and kernels.

c Number of samples analyzed to estimate mean and standard errors for anthraquinone residues. 
and kernel into $24 \mathrm{~mL}$ glass vials fitted with teflon lined caps. We pipetted $10 \mathrm{~mL}$ of methylene chloride into each vial using a glass volumetric pipette. We then recorded the weight of the extract. Extraction was accomplished by vortexing each vial for $20 \mathrm{~s}$, and then twice sonicating for $20 \mathrm{~min}$ (vortexing each time). We filtered a $0.7 \mathrm{~g}$ aliquot of each extract through a $0.2 \mu$ Nylon filter into a weighed evaporation vial. After capping, the evaporation vial was reweighed, and extract was evaporated to dryness under a gentle helium stream. The extract was dissolved using $2 \mathrm{~mL}$ of methanol and sonicated for $20 \mathrm{~min}$. Sample solutions were transferred into autosampler vials and analyzed by HPLC.

We used a five-point external calibration curve to calibrate our HPLC instrument. Samples were run in duplicate each day, and we checked single calibration points upon each 10 injections. The average response was plotted against anthraquinone concentrations. We used linear regression to calculate sample concentrations. The method detection limit (MDL) of our analyses was $0.010 \mathrm{ng} / \mathrm{mL}$.

\section{Results}

Residue analysis shows anthraquinone levels were substantially lower on kernels compared to corn husk samples (Table 1). The binary damage analysis for effect of anthraquinone treatment shows that red-winged blackbirds damaged fewer ears of sweet corn treated with anthraquinone than untreated ears of sweet corn $\left(F_{1,65}=5.60, P=0.021\right)$. Odds ratio analysis shows untreated sweet corn was 1.4 times more likely to experience redwing blackbird damage than treated sweet corn in our experiment (odds $=1.391,95 \% \mathrm{CI}=1.053,1.837$ ). The interaction between concentration level and treatment group was also significant; indicating that increasing levels of anthraquinone was associated with reduced damage to ripening sweet $\operatorname{corn}\left(F_{11,55}=3.19, P=0.002\right.$; Fig. 1$)$.

Percent of kernels consumed by red-winged blackbirds was lower on ears treated with anthraquinone than untreated ears of sweet corn $\left(F_{1,123}=4.90, P=0.029\right)$. Red-wing blackbirds consumed an average of $8.6 \% \pm 0.9 \%$ of kernels from untreated ears and $5.3 \% \pm 1.1 \%$ from ears treated with anthraquinone. The interaction of concentration level by treatment group was significantly

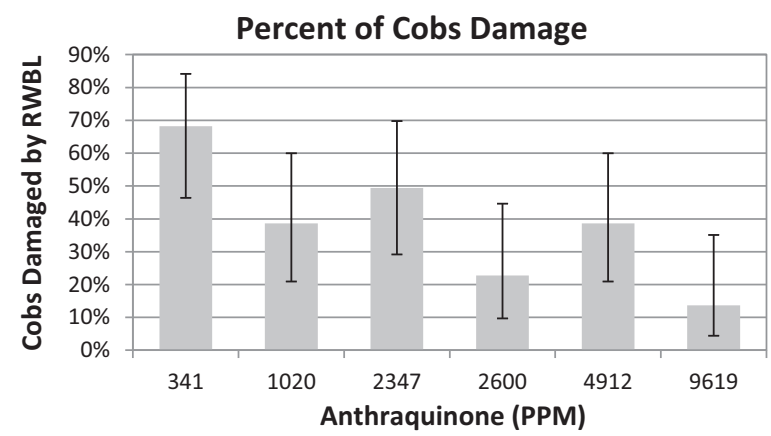

Fig. 1. Predicted plot and $95 \%$ confidence intervals for logistic regression model output of presence/absence of red-wing blackbird (RWBL) damage to ripening sweet corn.

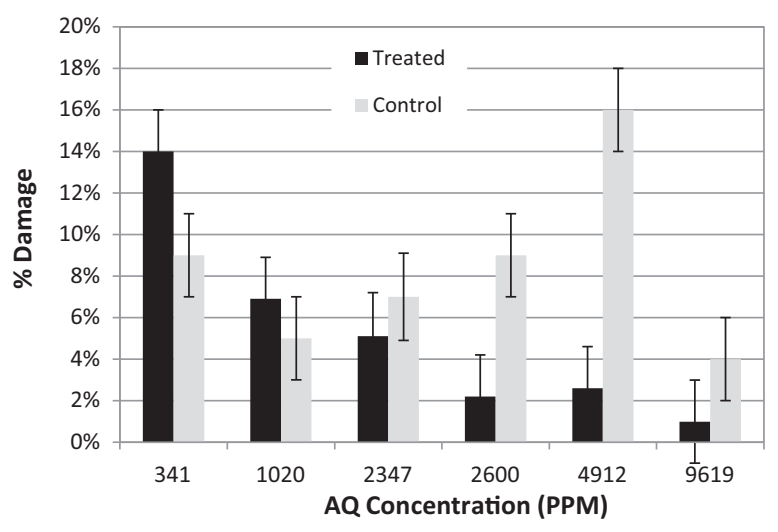

Fig. 2. Percent of kernels consumed from anthraquinone treated and untreated ears of sweet corn exposed to red-winged blackbirds.

associated with percent damage; suggesting that redwinged blackbird repellency increased with concentration of anthraquinone used in the experiment $\left(F_{11,45}=5.52\right.$, $P<0.001$; Fig. 2).

\section{Discussion}

The purpose of our study was to assess the efficacy of anthraquinone as a red-winged blackbird repellent for ripening corn. Our objectives were two-fold: first, demonstrate if anthraquinone can modify behavior thereby reducing bird depredation of ripening sweet corn; second, quantify the concentration-response of anthraquinone for red-winged blackbirds damaging ripening sweet corn. To achieve these goals, we conducted controlled feeding experiments using whole ears of milk stage sweet corn exposed to red-winged blackbirds. Our results suggest that anthraquinone was effective at reducing both the amount of corn consumed from ears as well as the total number of ears damaged.

We suspect that the economic impact from bird damage will be greater for sweet corn producers than field corn producers faced with similar levels of damage because of acceptable damage thresholds and the market value for whole ears of sweet corn. Even minimal bird damage to sweet corn can have a significant impact on the value of the crop. For ripening sweet corn a repellent must prevent birds from causing any damage whereas for field corn a repellent may only need to reduce the amount of kernels being consumed by birds to be economically beneficial to producers. This is why we analyzed separate models using two different metrics of damage: percent and binary response variables.

The percent and binary damage analyses suggest consumption of kernels and the odds of ears being damaged decreased as concentration of anthraquinone increased. These different analyses complement each other by adding depth to our understanding of how bird damage occurs. The percent damage analysis shows that application of anthraquinone-based repellents can effectively reduce red-winged blackbird consumption of kernels. Additionally, residue analysis shows this reduction in consumption occurred even though little to no anthraquinone was 
present on kernels. This suggests that contact with the anthraquinone on corn husks can effectively modify redwinged blackbird behavior and reduce consumption of kernels that have little to no anthraquinone exposure. Unfortunately this analysis cannot tell us if fewer ears of sweet corn were damaged by red-winged blackbirds. The binary damage analysis demonstrates that red-winged blackbirds exposed to anthraquinone also modified behavior in a manner that resulted in fewer ears of sweet corn being damaged and this reduction in damage was associated with increasing anthraquinone concentration. This suggests that red-winged blackbirds may be repelled from fields treated with anthraquinone when other food sources are available.

Results illustrated in Fig. 2 suggest percent of kernels consumed from treated ears, by red-winged blackbirds, decreased as anthraquinone concentration levels increased. Consequently, damage to untreated ears, with the exception of the lowest treatment group, increased as anthraquinone concentration increased, until red-winged blackbirds were exposed to corn treated with $2 \%$ AQ (9618 ppm). Among birds tested with 2\% AQ (9618 ppm) only $4 \%$ of kernels were eaten from untreated ears of sweet corn whereas birds exposed to $1 \%$ AQ (4911 ppm) consumed $16 \%$ of the kernels from untreated ears of sweet corn. In other words, red-winged blackbirds exposed to $2 \%$ AQ (9618 ppm) ate four times less untreated kernels than birds exposed to $1 \% \mathrm{AQ}$ (4911 ppm); suggesting exposure to the highest levels of anthraquinone reduced consumption of the untreated ears within the cage. This phenomenon has been documented previously. Red-winged blackbird exposure to anthraquinone reduced consumption on untreated rice in cage studies (Avery et al. (1997)). Thus, we hypothesize that red-winged blackbird exposure to high levels of anthraquinone will reduce damage to untreated sweet corn in close proximity to treated plants and this zone of protection will decrease as distance from the treated plant increases. We predict that corn husks treated with > $4911 \mathrm{ppm}$ anthraquinone will effectively repel redwinged blackbirds from untreated corn in close proximity to the treated plants.

Development of novel application strategies based upon the behavioral ecology of target organisms may provide safer and cost-effective tools for bird control in agriculture. Future research should test the efficacy of sacrificial plants as an application strategy for repelling blackbirds from ripening corn. These tests should assess the efficacy of different spatial configuration of sacrificial plant and the zone of protection they provide. Additionally, Werner et al. (2012) has shown that birds conditioned with Avipel, a UV-absorbent, postingestive repellent, avoided sunflower treated only with a UV absorbent cue. This suggests redwing blackbirds can be conditioned to avoid food sources, given a benign visual cue, if they have been previously exposed to anthraquinone. Other ecological studies suggest birds forage on insects within ripening corn prior to the onset of bird damage (Dolbeer, 1980). When we apply this existing knowledge to our corn data it suggests that early applications of anthraquinone, when birds are in fields but not consuming corn, followed by applications of a benign visual cue at milk stage may effectively reduce red-winged blackbird damage in a manner that reduces residues levels at harvest.

Anthraquinone residue levels on corn husks were substantially higher than the levels detected on kernels. This suggests that applications of anthraquinone to corn husks can reduce the number of ears damaged and the percent of kernels consumed by red-winged blackbirds without anthraquinone being applied directly to the edible kernels. We believe it is unlikely that any field applications, relying on aerial or tractor mounted spray equipment, would be able to saturate kernels more effectively than the immersion method used in our experiments. Thus, we believe the residue data we report for kernels may justify establishing a chemical tolerance for anthraquinone associated with food and feed use.

\section{Conclusions}

Improved understanding of bird depredation of agricultural crops and the development of effective methods to reduce the associated economic impacts will require an understanding of the evolutionary and ecological basis of bird feeding behavior (Avery, 2002). Through this work we built upon our understanding of bird behavior and repellent efficacy by analyzing multiple metrics of damage that help us better understand the feeding behavior of red-winged blackbirds. Our data demonstrate the efficacy of Avipel (a.i. 50\% 9,10-anthraquinone) as a red-winged blackbird repellent for ripening sweet corn while providing evidence that prior exposure to anthraquinone can reduce consumption of a food matrix that receives little to no direct anthraquinone exposure. Additionally, our data provides proof of concept that anthraquinone based repellents can be effective at repelling red-winged blackbirds from damaging ripening field corn.

\section{References}

Avery, M.L., 2002. Behavioural and ecological considerations for managing bird damage to cultivated fruit. In: Levey, D.J., Silva, W.R., Galetti, M. (Eds.), Seed Dispersal and Frugivory: Ecology, Evolution and Conservation. CAB International, Oxon, United Kingdom, pp. 467-477.

Avery, M.L., Humphey, J.S., Decker, D.G., 1997. Feeding deterrence of anthraquinone, anthracene, and anthrone to rice-eating birds. J. Wildl. Manage. 61, 1359-1365.

Blackwell, B.F., Helon, D.A., Dolbeer, R.A., 2001. Repelling sand hill cranes from corn: whole-kernel experiments with captive birds. Crop Protect. 20, 65-68.

Conover, M.R., 1984. Response of birds to different types of food repellents. J. Appl. Ecol. 21, 437-443.

Cummings, J.L., Avery, M.L., Mathre, O., Wilson, A.E., York, D.L., Engeman, R.M., Pochop, P.A., Davis Jr., J.E., 2002a. Field evaluation of Fligh Control $^{\mathrm{TM}}$ to reduce blackbird damage to newly planted rice. Wildl Soc. Bull. 30, 816-820.

Cummings, J.L., Pochop, P.A., Engeman, R.M., Davis Jr., J.E., Primus, T.M. 2002 b. Evaluation of Flight Control ${ }^{\circledR}$ to reduce blackbird damage to newly planted rice in Louisiana. Int. Biodeter. Biodeg. 49, 169-173.

DeGrazio, J.W., 1964. Methods to controlling blackbird damage to field corn in South Dakota. In: Proceedings of the Vertebrate Pest Conference, vol. 2, pp. 43-49.

Dolbeer, R.A., 1980. Blackbirds and corn in Ohio. United States Department of the Interior, Fish and Wildlife Service. Resource Publication, p. 136

Dolbeer, R.A., 1990. Ornithology and integrated pest management: redwinged blackbirds Agelaius phoeniceus and corn. IBIS 132, 309-322.

Eisemann, J.D., Werner, S.W., O'Hare, J.R., 2011. Registration considerations for chemical bird repellents in fruit crops. Outlooks Pest Manage. 22, 87-91. 
Erwin, A.T., 1951. Sweet corn-mutant or historic species. Econ. Bot. 5, 302-306.

Heckmanns, F., Meisenheimer, M., 1944. Protection of seeds against birds. Patent 2,339,335. US Patent Office, Washington, DC.

Klosterman, M., Linz, G.M., Slowik, A.A., Bleier, W.J., 2011. Assessment of bird damage to sunflower and corn in North Dakota. National Sunflower Association, Sunflower Research Forum, January 11-12, 2011. www.sunflowernsa.com/uploads/research/575/Klosterman_11.pdf

Linz, G.M., Homan, H.J., Slowik, A.A., Penry, L.B., 2006. Evaluation of registered pesticides as repellents for reducing blackbird (Icteridae) damage to sunflower. Crop Prot. 25, 842-847.

Martinez del Rio, C., 1990. Dietary, phylogenetic, and ecological correlates of intestinal sucrose and maltase activity in birds. Physiol. Zoo. 63, 987-1011.

Schultz, J.A., Juvik, J.A., 2004. Current models for starch synthesis and the sugary enhancer1 (se1) mutation in Zea mays. Plant Physiol. Biochem. 42, 457-464.

Stone, C.P., Mott, D.F., Besser, J.F., DeGrazio, J.W., 1972. Bird damage to corn in the United States in 1970. Wilson Bull. 84, 101-105.
Werner, S.J., Carlson, J.C., Tupper, S.K., Santer, M.M., Linz, G.M., 2009. Threshold concentrations of an anthraquinone-based repellent for Canada geese, red-winged blackbirds, and ring-necked pheasants. Appl. Anim. Behav. Sci. 121, 190-196.

Werner, S.J., Linz, G.M., Tupper, S.K., Carlson, J.C., 2010. Laboratory efficacy of chemical repellents for reducing blackbird damage in rice and sunflower crops. J. Wildl. Manage. 74, 1400-1404.

Werner, S.J., Tupper, S.K., Pettit, S.E., Carlson, J.C., Linz, G.M., 2011. Anthraquinone-based bird repellent for sunflower crops. Appl. Anim. Behav. Sci. 129, 162-169.

Werner, S.J., Tupper, S.K., Carlson, J.C., Petit, S.E., Ellis, J.W., Linz, G.M., 2012. The role of a generalized ultraviolet cue for blackbird food selection. Phys. Behav. 106, 597-601.

Woronecki, P.P., Dolbeer, R.A., Stehn, R.A., 1981. Response of blackbirds to Mesurol and Sevin applications on sweet corn. J. Wildl. Manage. 45, 693-701.

Wywialowski, A.P., 1993. Wildlife damage to field corn. Wild. Soc. Bull. 24, 264-271. 